Relations industrielles

Industrial Relations

\title{
H.W. ARTHURS, D.D. CARTER, F. FUDGE, H.J. GLASBEEK : Labour Law and Industrial Relations in Canada. 3rd ed., Toronto, Butterworths, 1988, 341 pp., ISBN 0-409-88891-5
}

\section{Pierre Verge}

\section{Volume 44, numéro 4, 1989}

URI : https://id.erudit.org/iderudit/050547ar

DOI : https://doi.org/10.7202/050547ar

Aller au sommaire du numéro

Éditeur(s)

Département des relations industrielles de l'Université Laval

ISSN

0034-379X (imprimé)

1703-8138 (numérique)

Découvrir la revue

Citer ce compte rendu

Verge, P. (1989). Compte rendu de [H.W. ARTHURS, D.D. CARTER, F. FUDGE, H.J. GLASBEEK : Labour Law and Industrial Relations in Canada. 3rd ed., Toronto, Butterworths, 1988, 341 pp., ISBN 0-409-88891-5]. Relations industrielles /

Industrial Relations, 44(4), 959-959. https://doi.org/10.7202/050547ar

Tous droits réservés @ Département des relations industrielles de l'Université Laval, 1989
Ce document est protégé par la loi sur le droit d'auteur. L'utilisation des services d'Érudit (y compris la reproduction) est assujettie à sa politique d'utilisation que vous pouvez consulter en ligne.

https://apropos.erudit.org/fr/usagers/politique-dutilisation/ 
Labour Law and Industrial Relations in Canada, by H.W. Arthurs, D.D. Carter, F. Fudge and H.J. Glasbeek, $3^{e}$ édition, Toronto, Butterworths, 1988, 341 pp., ISBN 0-409-88891-5, ISBN (Kluwer) 9065443894

Cette troisième édition réitère la substance des deux précédentes, respectivement recensées à (1986) 41 Relations industrielles 197 et à (1982) 37 Relations industrielles 241. Rappelons ici simplement que cet ouvrage, tiré de l'International Encyclopaedia for Labour Law and Industrial Relations, que dirige le professeur Roger Blanpain et que publie la maison Kluwer, constitue une très utile synthèse des principaux aspects du droit canadien du travail, particulièrement en ce qui a trait à l'ordre des rapports collectifs. Le lecteur, étranger surtout, appréciera une excellente mise en contexte de ce droit au regard des caractéristiques dominantes de l'économie et de la société canadiennes, $y$ compris des données essentielles sur le système politique et sur la réalité du syndicalisme canadien. Nous devons toutefois continuer de lui reprocher, d'un point de vue scientifique, une analyse juridique de l'arrière-plan législatif du rapport individuel (v. en part. les pp. 91 à 147) et des relations collectives de travail (v. en part. les pp. 247 et suivantes) exclusivement basée sur la Common law, à l'exclusion de l' «autre» système de droit privé du pays.

Les ajouts les plus intéressants de cette nouvelle édition tiennent compte des récents arrêts de la Cour suprême du Canada relatifs à la Charte canadienne des droits et libertés (Dolphin Delivery, Re Public Service Employee Relations Act (Alberta)...), de même que de l'influence grandissante des législations relatives aux droits de la personne et à l'égalité, notamment pour ce qui est de la formation et du contenu du contrat de travail (pp. 84 et suivantes). On trouve aussi une amplification intéressante au sujet des enquêtes et examens imposés par l'employeur au salarié (pp. 86 et suivantes).

Tout en conservant les indéniables qualités de clarté et de synthèse de l'ouvrage, une édition ultérieure pourrait réserver une plus large importance aux décisions du Conseil canadien des relations du travail et des instances québécoises. En passant, n'y aurait-il pas aussi avantage, en particulier pour le lecteur étranger, à citer la jurisprudence, notamment celle de la Cour suprême du Canada, à partir des recueils officiels, au lieu de se référer surtout à des compilations commerciales?

Pierre VERGE

Université Laval

Safety at Work: The Limits of Self-Regulation, by Sandra Dawson, Paul Willman, Martin Bamford and Alan Clinton, Cambridge, Cambridge University Press, 1988, 310 pp., ISBN 0-521-35497-8

Since the 1970s, governments in England, Canada and many other western countries have chosen to promote self-regulation as a major component of their occupational health and safety policies. That is, they have endorsed an approach to regulation in which the role of the state is to mandate or encourage the development of institutional arrangements in which employers and workers can be left to develop and implement the substance of regulatory policy. At the local level, this is reflected in statutes which require the creation of joint worker-employer health and safety committees and/or worker representatives, while at the national or provincial level, representatives of labour and capital are provided the opportunity to participate in the formulation of standards. Enthusiasm for this approach seems to be growing despite the absence of research evaluating its effectiveness. For example, in the spring of 1989 the government of Ontario introduced Bill 208 which contained a blueprint for the future development of occupational health and safety regulation characterized by more self-regulation. 